\section{Preliminary Nitrogen, Phosphorus, and Potassium DRIS Norms for Pineapple}

\author{
D.E. Angeles', M.E. Sumner, and N.W. Barbour \\ Department of Agronomy, University of Georgia, Athens, GA 30602
}

Additional index words. Diagnosis and Recommendation Integrated System, Ananas comosus, nutrient balance, foliar diagnosis

\begin{abstract}
Diagnosis and Recommendation Integrated System (DRIS) norms for pineapple [Ananas comosus (L.) Merr.] were developed from 1185 observations of previously published leaf nutrient composition and yield. The data were divided into highyielding ( $>60 \mathrm{t}^{\cdot} \cdot \mathrm{ha}^{-1}, 650$ observations) and low-yielding ( $<60 \mathrm{t} \cdot \mathrm{ha}^{-1}, 535$ observations) sub-populations and the norms derived by standard DRIS techniques. The validity of the norms was tested using independently published sets of data from factorial experiments in which yield responses to $N, P$, and $K$ had been obtained. In the case of most data sets, the new DRIS norms were able to make correct diagnoses where critical values failed to make any diagnoses for $N, P$, and $K$. Thus, the DRIS approach revealed nutrient deficiencies in the range normally considered to be sufficient. Increased precision is found in the evaluation of nutrient balance in the DRIS approach, which is ignored in the case of critical values.
\end{abstract}

Various workers (Godfrey-Sam-Aggrey, 1970; Kanapathy, 1958; Marchal et al., 1972; Pennock, 1944; Su, 1969) have diagnosed nutrient problems in pineapple based on leaf and soil analyses or a combination of both. The critical values or lower limits of sufficiency ranges used by these workers vary between $1.0 \%$ and $1.7 \%$ for $\mathrm{N}, 0.08 \%$ and $0.23 \%$ for $\mathrm{P}$, and $1.8 \%$ and $4.2 \%$ for $\mathrm{K}$. These ranges are too wide for use as diagnostic criteria if accuracy in revealing nutrient problems is desired. Although the importance of nutrient balance in determining yield and quality of crops has been known for some time, no means of readily quantifying it was available until the introduction of the Diagnosis and Recommendation Integrated System (DRIS) (Beaufils, 1973). The major advantage of this approach lies in its ability to minimize the effect of leaf age on diagnosis, enabling one to sample over a wider range of tissue age than permissible under the critical value approach. In addition, it gives a ranking of relative balance among nutrients in a tissue by means of indices that can have positive or negative values, with zero indicating balance. Furthermore, once DRIS norms have been established for a particular crop from a representative data bank incorporating all the variation likely to occur in the areas where the crop is cultivated, they are generally applicable to the crop wherever it might be grown (Beaufils, 1973). Thus,

Received for publication 1 May 1989. Research supported by U.S. Agency for International Development and Georgia Agricultural Experiment Stations. The cost of publishing this paper was defrayed in part by the payment of page charges. Under postal regulations, this paper therefore must be hereby marked advertisement solely to indicate this fact.

'Current address: Dept. of Horticulture, Univ. of the Philippines at Los Banes College, Laguna, Philippines. assessment of the nutritional status of plants can be easily made. Although, in pineapple, most diagnoses have been made using critical values, Langenegger and Smith (1978) reported using DRIS based on a rather limited data base, with limited verification of their norms.

The objective of the present study is to develop DRIS norms for pineapple from a large data set, and to validate and compare their efficacy with the critical value approach using independent data.

A data bank comprising 1185 observations of leaf nutrient concentrations and yields of pineapple fruit was developed as described previously by Sumner (1977a). The observations used came from the following countries: Philippines (Coronel, 1976; Eligio, 1978), Cameroon (Gaillard, 1971), Australia (Jorgensen, 1969; Jorgensen and Page, 1969), Honduras (A. McKay, personal communication), Ivory Coast (Lacoeuilhe, 1979; Lacoeuilhe and Guerot, 1976), South Africa (Langenegger and Smith, 1978), Taiwan (Su, 1957, 1958; Su and Li, 1962), Puerto Rico (Ramirez and Tejera, 1983; Samuels et al., 1955, 1958; Samuels and Gandia-Diaz, 1960), India (Rao et al., 1977; Subramanian et al., 1977), and Venezuela (Antoni and

Table 1. DRIS norms for pineapple from various sources.

\begin{tabular}{|c|c|c|c|c|c|c|}
\hline \multirow{2}{*}{$\begin{array}{l}\text { Form of } \\
\text { expression }\end{array}$} & \multicolumn{2}{|c|}{ Current study } & \multicolumn{2}{|c|}{$\begin{array}{l}\text { Derived from } \\
\text { critical } \\
\text { values }^{2}\end{array}$} & \multicolumn{2}{|c|}{$\begin{array}{l}\text { Langenegger and } \\
\text { Smith (1978) }\end{array}$} \\
\hline & Norm & $\overline{\mathrm{cv}(\%)}$ & Norm & $\mathrm{cv}(\%)$ & Norm & $\mathrm{cv}(\%)$ \\
\hline $\mathrm{N}$ & 1.43 & 22 & 1.43 & 20 & 1.52 & 21 \\
\hline P & 0.25 & 25 & 0.15 & 20 & 0.11 & 23 \\
\hline K & 3.24 & 26 & 2.77 & 20 & 2.76 & 26 \\
\hline $\mathrm{P} / \mathrm{N}$ & 0.18 & 31 & 0.11 & 20 & 0.07 & 26 \\
\hline $\mathrm{K} / \mathrm{N}$ & 2.30 & 26 & 1.94 & 20 & 1.70 & 34 \\
\hline $\mathrm{K} / \mathrm{P}$ & 13.90 & 40 & 18.35 & 20 & 25.51 & 33 \\
\hline
\end{tabular}

'For percent N, P, and $\mathrm{K}$, the norms arc the means of published critical values as explained in the text. The values for $\mathrm{P} / \mathrm{N}, \mathrm{K} / \mathrm{N}$, and $\mathrm{K} / \mathrm{P}$ were obtained arithmetically from percent $\mathrm{N}$, $\mathrm{P}$, and $\mathrm{K}$. Because it was not possible to calculate cv values in this case, a constant value of 20 was assigned arbitrarily. 


\begin{tabular}{|c|c|c|c|c|c|c|c|c|c|c|c|c|}
\hline \multirow{3}{*}{$\frac{\text { Treatment }}{\text { N P K }}$} & & \multirow{2}{*}{\multicolumn{4}{|c|}{ Concn $(\%)$}} & & & & \multicolumn{3}{|c|}{ Diagnosis } & \multirow{3}{*}{$\begin{array}{c}\text { Total } \\
\text { fruit } \\
\text { yield } \\
\left(\mathrm{t} \cdot \mathrm{ha}^{-1}\right) \\
\end{array}$} \\
\hline & & & & & & \multicolumn{3}{|c|}{$\begin{array}{l}\text { DRIS } \\
\text { indices }\end{array}$} & \multirow[b]{2}{*}{ DRIS } & $\begin{array}{c}\text { Critical } \\
\text { value }^{2} \\
\end{array}$ & $\begin{array}{c}\text { Mean } \\
\text { critical } \\
\text { valuey }^{2}\end{array}$ & \\
\hline & & $\mathrm{N}$ & $\mathrm{P}$ & & $\mathrm{K}$. & $\mathrm{N}$ & $\ddot{P}$ & $\mathrm{~K}$ & & $\mathrm{~N} P \mathrm{~K}$ & $\mathrm{~N} P \mathrm{~K}$ & \\
\hline 000 & & 0.97 & 0.47 & & 0.64 & 22 & 137 . & -159 & $\mathrm{~K}>\mathrm{N}>\mathrm{P}$ & $\downarrow \rightarrow \downarrow$ & $\downarrow \rightarrow \downarrow$ & 42.7 \\
\hline 001 & & 0.80 & 0.41 & & 3.57 & -46 & 35 & 11 & $\mathrm{~N}>\mathrm{K}>\mathrm{P}$ & $\downarrow \rightarrow \rightarrow$ & $\downarrow \rightarrow \rightarrow$ & 60.4 \\
\hline 101 & & 1.50 & 0.31 & & 2.18 & 10 & 13 & -23 & $\mathrm{~K}>\mathrm{N}>\mathrm{P}$ & $\rightarrow \rightarrow \downarrow$ & $\rightarrow \rightarrow \downarrow$ & 111 \\
\hline 102 & & 1.50 & 0.34 & & 3.53 & -4 & 7 & -3 & $\mathrm{~N}>\mathrm{K}>\mathrm{P}$ & $\rightarrow \rightarrow \rightarrow$ & $\rightarrow \rightarrow \rightarrow$ & 105 \\
\hline 202 & & 2.14 & 0.36 & & 3.95 & 7 & 1 & -8 & $\mathrm{~K}>\mathrm{P}>\mathrm{N}$ & $\rightarrow \rightarrow \rightarrow$ & $\rightarrow \rightarrow \rightarrow$ & 131 \\
\hline 010 & * & 0.83 & 0.42 & & 0.49 & 29 & 160 & -189 & $\mathrm{~K}>\mathrm{N}>\mathrm{P}$ & $\downarrow \rightarrow \downarrow$ & $\downarrow \rightarrow \downarrow$ & 41.3 \\
\hline 011 & & 0.67 & 0.54 & $\because$ & 3.29 & -75 & 70 & 5 & $\mathrm{~N}>\mathrm{K}>\mathrm{P}$ & $\downarrow \rightarrow \rightarrow$ & $\downarrow \rightarrow \rightarrow$ & 55.5 \\
\hline 111 & & 1.80 & 0.34 & & 2.80 & 9 & 9 & -18 & $\mathrm{~K}>\mathrm{N}=\mathrm{P}$ & $\rightarrow \rightarrow \downarrow$ & $\rightarrow \rightarrow \rightarrow$ & 107 \\
\hline 112 & & 1.50 & 0.39 & & 3.67 & -7 & 11 & -4 & $\mathrm{~N}>\mathrm{K}>\mathrm{P}$ & $\rightarrow \rightarrow \rightarrow$ & $\rightarrow \rightarrow \rightarrow$ & 117 \\
\hline 212 & $\because$ & 1.87 & 0.32 & & 3.59 & 5 & 2 & -7 & $\mathrm{~K}>\mathrm{P}>\mathrm{N}$ & $\rightarrow \rightarrow \rightarrow$ & $\rightarrow \rightarrow \rightarrow$ & 124 \\
\hline 020 & & $1.14^{\circ}$ & 0.48 & & 0.47 & 68 & 183 & -251 & $\mathrm{~K}>\mathrm{N}>\mathrm{P}$ & $\downarrow \rightarrow \downarrow$ & $\downarrow \rightarrow \downarrow$ & 32.8 \\
\hline 021 & & 0.80 & 0.56 & & 3.38 & -61 & 61 & 0 & $\mathrm{~N}>\mathrm{K}>\mathrm{P}$ & $\downarrow \rightarrow \rightarrow$ & $\downarrow \rightarrow \stackrel{ }{\rightarrow}$ & 62.5 \\
\hline 121 & & 1.57 & 0.41 & & 2.78 & -1 & 19 & -18 & $\mathrm{~K}>\mathrm{N}>\mathrm{P}$ & $\rightarrow \rightarrow \downarrow$ & $\rightarrow \rightarrow \rightarrow$ & 97.8 \\
\hline 122 & & 1.64 & 0.38 & & 3.77 & -4 & 8 & -4 & $\mathrm{~N}=\mathrm{K}>\mathrm{P}$ & $\rightarrow \rightarrow \rightarrow$ & $\rightarrow \rightarrow \rightarrow$ & 110 \\
\hline 222 & & 1.80 & 0.32 & & 2.64 & 12 & 8 & -20 & $\mathrm{~K}>\mathrm{P}>\mathrm{N}$ & $\rightarrow \rightarrow \downarrow$ & $\rightarrow \rightarrow \downarrow$ & 134 \\
\hline 000 & & 0.97 & 0.47 & & 0.64 & 22 & 137 & -159 & $\mathrm{~K}>\mathrm{N}>\mathrm{P}$ & $\downarrow \rightarrow \downarrow$ & $\downarrow \rightarrow \downarrow$ & 42.7 \\
\hline 010 & . & 0.83 & 0.42 & & 0.49 & 29 & 160 & -189 & $\mathrm{~K}>\mathrm{N}>\mathrm{P}$ & $\downarrow \rightarrow \downarrow$ & $\downarrow \rightarrow \downarrow$ & 41.3 \\
\hline 020 & & 1.14 & 0.48 & . & 0.47 & 68 & 183 & -251 & $\mathrm{~K}>\mathrm{N}>\mathrm{P}$ & $\downarrow \rightarrow \downarrow$ & $\downarrow \rightarrow \downarrow$ & 32.8 \\
\hline 101 & & 1.50 & 0.31 & & 2.18 & 10 & 13 & -23 & $\mathrm{~K}>\mathrm{N}>\mathrm{P}$ & $\rightarrow \rightarrow \downarrow$ & $\rightarrow \rightarrow \downarrow$ & 111 \\
\hline 111 & & 1.80 & 0.34 & & 2.80 & 9 & 9 & -18 & $\mathrm{~K}>\mathrm{N}=\mathrm{P}$ & $\rightarrow \rightarrow \downarrow$ & $\rightarrow \rightarrow \rightarrow$ & 107 \\
\hline 121 & & 1.57 & 0.41 & & 2.78 & -1 & 19 & -18 & $\mathrm{~K}>\mathrm{N}>\mathrm{P}$ & $\rightarrow \rightarrow \downarrow$ & $\rightarrow \rightarrow \rightarrow$ & 97.8 \\
\hline 202 & & 2.14 & 0.35 & & 3.94 & 7 & 1 & -8 & $\mathrm{~K}>\mathrm{P}>\mathrm{N}$ & $\rightarrow \rightarrow \rightarrow$ & $\rightarrow \rightarrow \rightarrow$ & 131 \\
\hline 212 & & 1.87 & 0.32 & .. & 3.58 & 5 & 2 & -7 & $\mathrm{~K}>\mathrm{P}>\mathrm{N}$ & $\rightarrow \rightarrow \rightarrow$ & $\rightarrow \rightarrow \rightarrow$ & 124 \\
\hline 222 & & 1.80 & 0.32 & - & 2.62 & 12 & 8 & -20 & $\mathrm{~K}>\mathrm{P}>\mathrm{N}$ & $\rightarrow \rightarrow \rightarrow$ & $\rightarrow \rightarrow \rightarrow$ & 134 \\
\hline
\end{tabular}

${ }^{2}$ Pan (1957): $\mathrm{N}=1.5 \%, \mathrm{P}=0.31 \%, \mathrm{~K}=2.9 \%$.

'Mean: $\mathrm{N}=1.43 \%, \mathrm{P}=0.15 \%, \mathrm{~K}=2.77 \%$.

Table 3. Comparison of DRIS and critical nutrient level in making correct diagnoses in pineapple on data of Pan (1957) using the norms derived from the current study, critical nutrient level, and from Langenegger and Smith (1978).

\begin{tabular}{|c|c|c|c|c|c|c|c|c|}
\hline \multirow[b]{2}{*}{ Yield } & \multirow[b]{2}{*}{ Norm } & \multirow[b]{2}{*}{ Source } & & \multicolumn{4}{|c|}{ Correct response } & \multirow{2}{*}{$\begin{array}{c}\text { Percent } \\
\text { successful } \\
\text { diagnoses }\end{array}$} \\
\hline & & & & $\mathrm{N}$ & $\mathrm{P}$ & $\mathrm{K}$ & Total & \\
\hline Fruit & $\begin{array}{r}\text { Critical } \\
\text { level }\end{array}$ & $\begin{array}{l}\text { Current study } \\
\text { Derived from } \\
\text { critical value } \\
\text { Langenegger } \\
\text { and Smith (1978) }\end{array}$ & $\begin{array}{l}\text { No. }{ }^{z} \\
\text { Yieldy } \\
\text { No. } \\
\text { Yield } \\
\text { No. } \\
\text { Yield } \\
\text { No. } \\
\text { Yield }\end{array}$ & $\begin{array}{c}9.0 \\
346 \\
9.0 \\
346 \\
10.0 \\
350 \\
6.0 \\
288\end{array}$ & $\begin{array}{l}0 \\
0 \\
0 \\
0 \\
0 \\
0 \\
0 \\
0\end{array}$ & $\begin{array}{c}13.0 \\
425 \\
13.0 \\
425 \\
12.0 \\
413 \\
11.0 \\
403\end{array}$ & $\begin{array}{c}22.0 \\
771 \\
22.0 \\
771 \\
22.0 \\
788 \\
17.0 \\
692\end{array}$ & $\begin{array}{l}92 \\
92 \\
71\end{array}$ \\
\hline $\begin{array}{l}\text { Plant } \\
\text { bodyx }\end{array}$ & $\begin{array}{r}\text { Critical } \\
\text { level }\end{array}$ & $\begin{array}{l}\text { Current study } \\
\text { Derived from } \\
\text { critical value } \\
\text { Langenegger } \\
\text { and Smith (1978) }\end{array}$ & $\begin{array}{l}\text { No. } \\
\text { Yield } \\
\text { No. } \\
\text { Yield } \\
\text { No. } \\
\text { Yield } \\
\text { No. } \\
\text { Yield }\end{array}$ & $\begin{array}{c}9.0 \\
299 \\
9.0 \\
299 \\
10.0 \\
320 \\
6.0 \\
234\end{array}$ & $\begin{array}{l}0 \\
0 \\
0 \\
0 \\
0 \\
0 \\
0 \\
0\end{array}$ & $\begin{array}{l}15.0 \\
692 \\
15.0 \\
692 \\
14.0 \\
669 \\
13.0 \\
646\end{array}$ & $\begin{array}{c}24.0 \\
991 \\
24.0 \\
991 \\
24.0 \\
989 \\
18.0 \\
881\end{array}$ & $\begin{array}{r}100 \\
100 \\
79\end{array}$ \\
\hline
\end{tabular}

${ }^{z}$ Number of correct diagnoses out of 24 treatments.

${ }^{y}$ Sum of yield increases $\left(\mathrm{kg} \cdot \mathrm{ha}^{-1}\right)$ over the entire experiment when nutrient levels were diagnosed as insufficient by the appropriate diagnostic method.

${ }^{x}$ Reference did not give details, but we assumed that it refers to the weight of the aerial vegetative parts.

likely to represent the range of variation experiericed in pineapple production areas. However, an" independent test of the diagnostic precision of the norms relative to that of the critical values is necessary to support this claim.

A comparison of the diagnostic accuracy of the two approaches is made in Table 2 using independent data from an experiment in which significant yield responses were ob- tained to $\mathrm{N}$ and $\mathrm{K}$, but not $\mathrm{P}$ treatments (Pan, 1957). Beginning with the control treatment (0N-OP-0K), both approaches diagnose $\mathrm{K}$ and $\mathrm{N}$ as being limiting, and, when these nutrients are applied, yield generally increases until treatment $1 \mathrm{~N}-0 \mathrm{P}-2 \mathrm{~K}$ is reached, at which point the critical value approach indicates that $\mathrm{N}, \mathrm{P}$, and $\mathrm{K}$ are adequate, but the DRIS approach diagnoses $\mathrm{N}$ to be most limiting. Application of $\mathrm{N}$ in treatment $2 \mathrm{~N}$ -
$0 \mathrm{P}-2 \mathrm{~K}$ results in a further yield increase, indicating that the diagnosis by DRIS was correct. Thus, the DRIS approach was able to make diagnoses that resulted in the treatment with the highest yield in the experiment being reached, whereas the critical value approach was less successful. When a different starting point was chosen, such as treatment $0 \mathrm{~N}$ $1 \mathrm{P}-0 \mathrm{~K}$, a similar result is obtained, with the DRIS approach being superior to that of the 


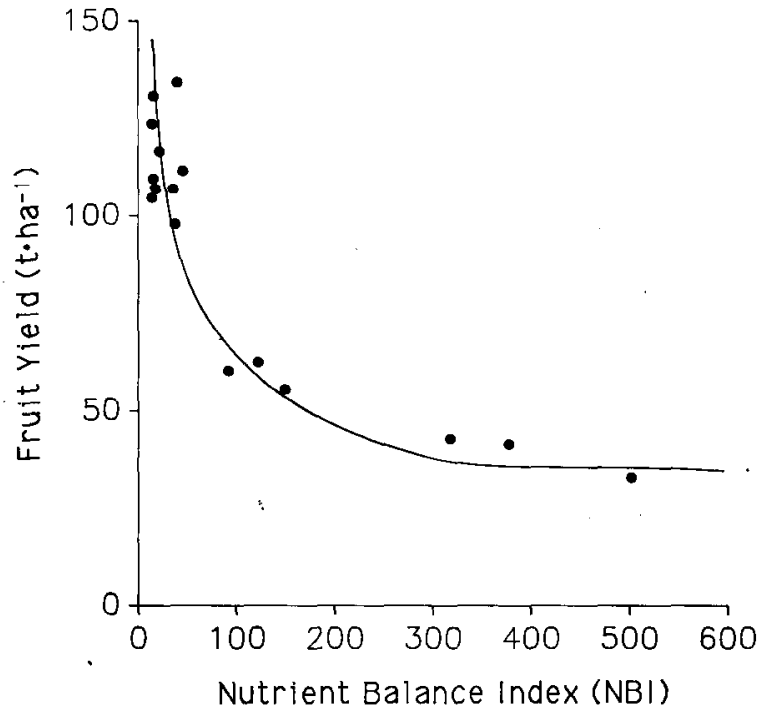

Fig. 1. Relationship between nutrient balance index and fruit yield of pineapple using data from Pan (1957).

Table 4. DRIS diagnosis of the nutritional requirements of pineapple treated with $\mathrm{N}$ and $\mathrm{K}$ using the data of Eligio (1978).

\begin{tabular}{|c|c|c|c|c|c|c|c|c|c|}
\hline \multicolumn{2}{|c|}{$\begin{array}{c}\text { Treatment } \\
\text { (g/plant) }\end{array}$} & \multicolumn{3}{|c|}{ Concn $(\%)$} & \multicolumn{3}{|c|}{ DRIS indices } & \multirow{2}{*}{$\begin{array}{l}\text { Order of } \\
\text { requirements }\end{array}$} & \multirow{2}{*}{$\begin{array}{c}\text { Fruit w } \\
(\mathrm{kg})^{z}\end{array}$} \\
\hline $\mathrm{N}$ & $\mathrm{K}$ & $\mathrm{N}$ & $P$ & $\mathrm{~K}$ & $\mathrm{~N}$ & $\mathrm{P}$ & K & & \\
\hline 0 & 0 & 0.77 & 0.35 & 2.92 & -36 & 32 & 4 & $\mathrm{~N}>\mathrm{K}>\mathrm{P}$ & 1.04 \\
\hline 0 & 10 & 0.51 & 0.26 & 2.82 & -56 & 32 & 23 & $\mathrm{~N}>\mathrm{K}>\mathrm{P}$ & 1.01 \\
\hline 0 & 20 & 0.72 & 0.30 & 3.55 & -42 & 23 & 20 & $\mathrm{~N}>\mathrm{K}>\mathrm{P}$ & 1.51 \\
\hline 10 & 0 & 0.96 & 0.11 & 2.75 & 5 & -20 & 15 & $\mathrm{P}>\mathrm{N}>\mathrm{K}$ & 1.82 \\
\hline 10 & 10 & 0.89 & 0.13 & 3.32 & -8 & -15 & 22 & $\mathrm{P}>\mathrm{N}>\mathrm{K}$ & 2.01 \\
\hline 10 & 20 & 0.91 & 0.15 & 3.25 & -9 & -9 & 18 & $\mathrm{P}=\mathrm{N}>\mathrm{K}$ & 1.66 \\
\hline 20 & 0 & 1.00 & 0.12 & 2.67 & 5 & -16 & 11 & $\mathrm{P}>\mathrm{N}>\mathrm{K}$ & 1.54 \\
\hline 20 & 10 & 1.00 & 0.11 & 2.75 & 7 & -21 & 14 & $\mathrm{P}>\mathrm{N}>\mathrm{K}$ & 1.77 \\
\hline 20 & 20 & 1.07 & 0.10 & 3.33 & 9 & -33 & 24 & $\mathrm{P}>\mathrm{N}>\mathrm{K}$ & 1.72 \\
\hline
\end{tabular}

${ }^{7}$ Mean separations presented by Eligio (1978) are not given because the statistical treatment was inappropriate.

critical value. When treatment $0 \mathrm{~N}-2 \mathrm{P}-0 \mathrm{~K}$ was selected as a starting point, both systems had equal accuracy. If an inappropriate treatment (one that is not limiting) were applied, one would expect little or no increase in yield, as shown when the process starts with either treatments $1 \mathrm{~N}-0 \mathrm{P}-1 \mathrm{~K}$ or $2 \mathrm{~N}-0 \mathrm{P}-2 \mathrm{~K}$. Application of $\mathrm{P}$ in these cases either increases the requirement for $\mathrm{K}$ or results in no change or a decrease in yield. In all cases, as the limiting nutrients are supplied, the nutrient balance index (NBI), being the sum of the DRIS indices irrespective of sign, progressively decreases to a low value, thus indicating that nutrition is coming into balance (Beaufils, 1973). When an inappropriate treatment is applied the reverse is true. As has been shown previously (Sumner, 1977b), a strong inverse relationship should exist between yield and NBI (Fig. 1). This relationship clearly illustrates the importance of nutrient balance in determining the yield of a crop.

A summary of such diagnostic comparisons using two sets of DRIS norms (current study and those of Langenegger and Smith, 1978) and the norms derived by taking the appropriate ratios of the critical values is presented in Table 3 for all the data presented by Pan (1957). In the case of both forms of expressing yield (fruit or plant weight), the DRIS norms obtained in the current study had superior precision over the others. The fact that the norms derived from critical levels proved to be as effective as those derived from the data base points to the importance of assessing nutrient balance when making diagnoses. By calculating the ratios of the critical values, balance is automatically built into the diagnosis, which the critical value approach is unable to do.

Comparison of the diagnostic precision of the two systems using the data of Eligio (1978) showed that they were equally effective, but, because of the limited nature of his data set, it was impossible to test whether a response to $\mathrm{P}$ would have been obtained (Table 4).

The DRIS norms derived in the current study have proven to be better diagnostic parameters than were the critical values for assessing the most-limiting nutrient among $\mathrm{N}$, $\mathrm{P}$, and $\mathrm{K}$ for pineapples and are therefore offered as preliminary norms suitable for further testing. However, before the DRIS approach can be applied more effectively to pineapple, it will be necessary to derive norms for the other essential elements.

\section{Literature Cited}

Antoni, M.G.S. and F.P. Leal. 1979. Efecto de la fertilization (N-P-K) sobre el rendimiento y calidad de la pina 'Espanola Roja'. Proc. Trop. Reg. Amer. Soc. Hort. Sci. 23:163-168.

Beaufils, E.R. 1973. Diagnosis and Recommendation Integrated System (DRIS). Soil Sci. Bul. 1., Univ. of Natal, S. Afr.

Coronel, R.E, 1976. The NPK requirements of 'Smooth Cayenne' pineapple (Ananas comosus). UPLB-NFAC Fruit Research, Training and Extension Program Annu. Rpt. Univ. Philippines, Los Banes College, Laguna.

Dalldorf, D.B. and W. Langenegger. 1978. Macroelement fertilization of 'Smooth Cayenne' pineapples. Farming in S. Afr., Pineapple Ser. E 2.

Eligio, D.T. 1978. Nutrient composition of the different parts of 'Smooth Cayenne' pineapple as influenced by varying levels of $\mathrm{N}$ and $\mathrm{K}$ fertilization. MS Thesis, Univ. Philippines, Los Banes College, Laguna.

Gaillard, J.P. 1971. An investigation of the K/N balance for production of fresh pineapples in the Cameroon Republic. I. Agronomic results. Potash Rev., Subject 27.55:1-13.

Glennie, J.D. 1977. Pineapple nutrition. Hort. Branch Adv. Lflt. 34.

Godfrey-Sam-Aggrey, W. 1970. Foliar analysis as a guide to NPK nutrition of pineapples in the forest zone of Ghana. Expt. Agr. 6:327-333.

Jorgensen, K.R. 1969. Investigation of pineapple fertilizing methods and flower induction. Queensland J. Agr. \& Animal Sci. 26:484-493.

Jorgensen, K.R. and P.E. Page. 1969. Comparison of four fertilizer schedules for pineapples in Central Queensland. Queensland J. Agr. \& Animal Sci. 26:495-508

Kanapathy, K. 1958. Leaf analysis in relation to yield and quality of pineapples. Malayan Agr. J. 41:18-26.

Lacoeuilhe, J.J. 1979. N-K manuring of the pineapple in the Ivory Coast. Potash Rev., Subject 27.89:1-9

Lacoeuilhe, J.J. 1987. Pineapple, p. 600-617. In: P. Martin-Prevel, J. Gagnard, and P. Gautier (eds.). Plant analysis as a guide to the nutrient requirements of temperate and tropical crops. Lavoisier, New York.

Lacoeuilhe, J.J. and R. Guerot. 1976. Action dunematode $P$. brachyurus sur la croissance, la nutrition et les rendements de l'ananas. Influence de la localization de fumure. Fruits 31: 147156.

Langenegger, W. and B.L. Smith. 1978. An evaluation of the DRIS system as applied to pineapple leaf analysis, p. 263-273. In: A.R. Ferguson, R.L. Bieleski, and I.B. Ferguson (eds.). Proc. 8th Intl. Colloq. Plant Anal. \& Fert. Problems, Auckland, New Zealand.

Letzsch, W.S. and M.E. Sumner. 1984. Effect of population size and yield level in selection of Diagnosis and Recommendation Integrated System (DRIS) norms. Commun. Soil Sci. \& Plant Anal. 15:997-1006.

Marchal, J. 1971. Le phosphore chez l'ananas. Fruits 26:189-206.

Marchal, J., P.M. Martin-Prevel, J.J. Lacoeuilhe, and P. Lassois. 1972. An investigation of the $\mathrm{K} / \mathrm{N}$ balance for production of fresh pineapples in the Cameroon Republic. II. Leaf analysis. Potash Rev., Subject 27.55: 1-13.

Pan, K.Y. 1957. Research on the three essential fertilizers for pineapples. J. Agr. Assn. China 19:111-129.

Pennock, W. 1944. Field response of red spanish pineapples to nitrogen, calcium, iron and soil pH. J. Agr,. Univ. Puerto Rico 33:1-26.

Ramirez, C.T. and E.G. Tejera. 1983. Spacing, nitrogen and potassium on yield and quality of 'Cabezona' pineapple. J. Agr. Univ. Puerto Rico 67:1-10. 
Rae, M. H., T.R. Subramanian, N.K. Srinivasa Murthy, H.P. Singh, H.C. Dass, and K.M. Ganapathy. 1977. Leaf nitrogen status as influenced by varying levels of nitrogen application and its relationship with yield in 'Kew' pineapple. Scientia Hort. 7:137-142.

Reuter, D.J. and J.B. Robinson. 1987. Plant analysis, an interpretation manual. Inkata Press, Melbourne, Australia.

Samuels, G., S. Alers-Alers, and G.C. Jackson. 1958. Influence of fertilizers on yields of pineapples on a Cato clay. J. Agr. Univ. Puerto Rico 42:12-26.

Samuels, G. and H. Gandia-Diaz. 1960. A comparison of the yield and nutrition requirements of the 'Red Spanish' and 'Smooth Cayenne' pineapples. Proc. Carib. Reg. Amer. Soc. Hort. Sci. 4:41-47.

Samuels, G., P. Landrau, Jr., and R. Olivencia.
1955. Response of pineapples to the application of fertilizers. J. Agr. Univ. Puerto Rico 39:111.

Steyn, W.J.A. 1961. The errors involved in the sampling of citrus and pineapple plants for leaf analysis purposes, p. 409-430. In: W. Reuther (cd.). Plant analysis and fertilizer problems. Publ. 8, Amer. Inst. of Biol. Sci., Washington, D.C.

$\mathrm{Su}$, N.R. 1957. An experiment on the nitrogen requirement of pineapples. J. Agr. Assn. China 18:18-46.

$\mathrm{Su}$, N.R. 1958. The response of pineapples to the application of potassium chloride. J. Agr. Assn. China 22:27-50.

Su, N.R. 1969. Recommendations on the nutritional management, of pineapple in Taiwan. Potash Rev., Subject 27, 48th Suite. p. 1-8.

$\mathrm{Su}$, N.R. and C.Y. Li. 1962. Comparison of two potassium salts as regards their effects on the yield and quality of pineapple fruits. J. Agr. Assn. China 39:31-42.

Subramanian, T. R., H.K. Srinavasa Murthy, K.L. Chadha, and K.R. Melanta. 1977. Leaf N, P, $\mathrm{K}$ status and yield as influenced by sources of nitrogen and potassium and their relationship in pineapple. Indian J. Hort. 34:335-341.

Sumner, M.E. 1977a. Preliminary NPK diagnostic norms for wheat. Commun. Soil Sci. \& Plant Anal. 8:149-167.

Sumner, M.E. 1977b. Use of the DRIS system in foliar diagnosis of crops at high yield levels. Commun. Soil Sci. \& Plant Anal. 8:251-268.

Sumner, M.E. and E.R. Beaufils. 1975. Diagnosis of the N, P, K requirements of sugarcane irrespective of plant age and season using Beaufil's system (DRIS)-Preliminary observations. Proc. S. Afr. Sugar Tech. Assn. 49:447-458.

\title{
Nitrogen and Phosphorus Preconditioning of Small-plug Seedlings Influence Processing Tomato Productivity
}

\author{
Ronald W. Garton \\ Agriculture Canada, Research Station, Harrow, Ont. NOR 1G0, Canada \\ Irvin E. Widders \\ Department of Horticulture, Michigan State University, East Lansing, \\ MI 48824-1112
}

Additional index words. Lycopersicon esculentum, fertilization, transplant, field est abolishment

\begin{abstract}
Seedlings of processing tomato 'H 2653' (Lycopersicon esculentum Mill.) were cultured in 288 -cell ( $<6 \mathrm{~cm}^{3}$ volume) plug trays in a soilless growing medium. Pretransplant fertilization with nutrient solutions containing 10 or $20 \mathrm{~mm} \mathrm{~N}$ and 2 or $5 \mathrm{~mm} P$ for 10 days altered the total ammoniacal-N and $\mathrm{P}$, and the soluble $\mathrm{NO}_{3}-\mathrm{N}$ and $\mathrm{PO}_{4}-\mathrm{P}$ concentrations in the shoot tissue at transplanting. Post-transplanting shoot and root growth were more rapid in late May plantings than in earlier plantings. The 20mм $N$ and 2-mм $P$ pretransplant treatment caused the most rapid shoot growth following early season plantings in the field. Rapid seedling establishment after transplanting was generally not a good indicator of potential fruit yield. The 5-mM $P$ pretransplant treatment produced higher marketable fruit yields in early plantings but not in later. Culture of seedlings under a low fertilization regime $(5.4 \mathrm{~mm} \mathrm{~N}, 1.0 \mathrm{~mm}$ $P$, and $1.6 \mathrm{~mm} \mathrm{~K}$ ) before pretransplant treatment produced as high or higher fruit yields than did seedlings from a higher regimen. Withholding fertilizer temporarily before transplanting resulted in a depletion in tissue $\mathbf{N}$ and $P$ concentrations, slow posttransplanting shoot growth, and lower yields.
\end{abstract}

Vegetable seedlings cultured for transplanting in small-size plug cells require careful management (Dufault and Waters, 1985; Weston, 1988) due to the volume limitations of the cell $\left(<6 \mathrm{~cm}^{3}\right)$ and the high seedling

Received for publication 3 Aug. 1989. Michigan Agricultural Experiment Station Journal article no. 13141. The cost of publishing this paper was defrayed in part by the payment of page charges. Under postal regulations, this paper therefore mus be hereby marked advertisement solely to indicate this fact. densities within the tray $\left(\approx 28\right.$ plants $\left./ 100 \mathrm{~cm}^{2}\right)$. Essential nutrient elements within the cell plug are frequently insufficient to sustain plant growth for an extended period. A proposed fertilization scheme (Widders, 1989) for culture of tomato seedlings involves application of moderately low-concentration nutrient solutions (e.g., 4.3. mm N, $0.8 \mathrm{~mm} \mathrm{P}$, and 1.3 $\mathrm{mM} \mathrm{K}$ ) throughout the first 3 to 5 weeks of growth, followed by treatment with high concentrations of $\mathrm{N}$ and $\mathrm{P}$ for 5 to 10 days before transplanting. This fertilization strategy has two distinct advantages for small plug-cell seedling culture: 1) Vegetative growth of seedlings can be controlled by limiting initial supply of nutrients, thus reducing the potential for root binding or excessive stem elongation; 2) $\mathrm{N}$ and $\mathrm{P}$ content within the seedling tissue can be enhanced before transplanting, which is important for rapid plant establishment and nutrient uptake from the soil thereafter (Widders, 1989).

The objective of this study was to determine the influence of pretransplant fertilization with $\mathrm{N}$ and $\mathrm{P}$ of small plug-cell cultured processing tomato seedlings on field establishment and ultimate fruit yield. The effects of field environmental conditions, as determined by time of planting, on seedling response to the pretransplant treatments were also evaluated.

Field experiments were conducted at the Agriculture Canada Research Station at Harrow, Ont., during Summer 1986 and 1987 and at the Michigan State Univ. Horticulture Research Center, East Lansing, during 1987. The soil at Harrow was a Fox sandy loam (Brunisolic gray brown Luvisol Typic Hapludalf) with a $\mathrm{pH}$ of 6.4. Nitrogen (80 $\mathrm{kg} \cdot \mathrm{ha}^{-1}$ ) was applied as ammonium nitrate to the field before planting. At East Lansing, the soil was a Spinks sandy loam (Psammentic sandy, mixed, mesic, Hapludalfs) with a $\mathrm{pH}$ of 6.3 and a cation exchange capacity of 4 . The soil was preplant fertilized with $\left(\mathrm{kg} \cdot \mathrm{ha}^{-1}\right) 80 \mathrm{~N}-160 \mathrm{P}-160 \mathrm{~K}$.

In all three experiments, seeds of ' $\mathrm{H} 2653$ ' (H.J. Heinz Co.) processing tomato were sown in 288-cell plug trays (TLC Polyform, Plymouth, Minn.) containing ASB medium (ASB Greenworld, Waterloo, Ont.), a peatbased variation of the Cornell mix. Individual cells were tapered with a volume of $<6$ $\mathrm{cm}^{3}(2 \times 2 \times 2 \mathrm{~cm}$ length, width, depth). The seedlings were cultured in a greenhouse with no supplemental lighting.

At Harrow, seeds were sown on 1 and 16 Apr. 1986 and 24 Mar. and 16 Apr. 1987. Seedlings were fertilized three times weekly with soluble fertilizer $(20 \mathrm{~N}-8.6 \mathrm{P}-16.6 \mathrm{~K})$ at $0.3 \mathrm{~g} \cdot \operatorname{liter}^{-1}(4.3 \mathrm{~N}-0.8 \mathrm{P}-1.3 \mathrm{~K} ; \mathrm{mm})$. When the seedlings were 4 to 5 weeks old, $\approx 12$ $\mathrm{cm}$ high, four pretransplant fertilization 